\title{
Synthesis and characterization of stable aqueous dispersion of silver nanoparticle from citrullus vulgaris seed oil via lecithin
}

\author{
Henry L. Barnabas ${ }^{a,}{ }^{*}$, A. M. Ngoshe ${ }^{b}$, Joshua A. Gidigbi a (i)
}

a Group Research in Green and Physical Chemistry, Department of Chemistry, Modibbo Adama University of Technology, Yola, Adamawa State Nigeria.

b Department of Chemistry, Federal College of Education, Yola, Adamawa State Nigeria.

*Corresponding author Email: henrylingweb@gmail.com

DOI: https://doi.org/10.34256/nnxt2122

Received: 02-04-2021; Revised: 01-06-2021; Accepted: 02-06-2021; Published: 03-06-2021

Abstract: Nanoparticles are known to be of wide applications in various fields of human endeavours. Many methods of syntheses such as physical, chemical are harmful to the environment, thus, this study utilised green production of nanoparticles via waste product such as Citrulus vulgaris seed. Oil was extracted using soxhlet extractor from the prepared Citrulus vulgaris seed. Physico-chemical properties such as percentage yield, acid value, peroxide value were carried out on the Citrulus vulgaris seed oil. Citrulus vulgaris was further processed to form lecithin. The lecithin extracted was characterized for colour, Peroxide Value, Acetone Insoluble (AI), Acid Value, solubility in water and organic solvents. The result of the physico-chemical parameters was in conformity with the standard and various literatures. Therefore, lecithin is processed into dispersed aqueous silver nanoparticles by the addition of silver nitrate. The chemical reaction was monitored progressively using visual assessment, UV-visible and FTIR Spectroscopy. The size and surface of the dispersed silver nanoparticles produced was analysed using Atomic Force Microscopy. Therefore, a dispersed aqueous silver nanoparticle was produced from lecithin made from Citrulus vulgaris seed oil.

Keywords: ZnO, Spectroscopic studies, Optical, Structural

\section{Introduction}

The nanoparticles are small particles that range between 1 to 100 nanometres in size. Noble metal nanoparticles find promising applications in fields ranging from nanotechnology to biotechnology due to their unique shape and size-dependent optical and electronic properties [1, 2]. According to Hoshyar, et al., 2016; Kamala et al., 2020 [3, 4], at the introduction of light energy, noble metal nanoparticles show wavelength selective photon absorption and huge enhancement in local electric fields, due to a phenomenon known as surface plasmon resonance (SPR), which forms the basis of their diverse applications. Among the noble metal nanoparticles, silver nanoparticles exhibit the strongest SPR absorption and find widespread applications in sensing; photonics, wide application as a catalysis, medicine, antimicrobials and surface enhanced Raman spectroscopy [5-8].

Silver nanoparticles had been produced by various physical and chemical methods $[8,9]$. While the physical methods are costly, chemical methods employ toxic and hazardous chemicals which pose serious threat to the environment and the prepared silver nanoparticles can have adverse effects in biomedical applications because of the toxic chemicals adsorbed on their surface [7, 10-12]. In the light of these setbacks, biosynthesis becomes alternative route to safe synthesis of silver nanoparticles.

According to Gidigbi, et al., 2019 [13], the quest to annex a renewable source of raw materials and to address the ever-increasing pollution in the society, mostly created by unit process and unit operation of an industrial activities, necessitates research into plant materials, especially to leverage on its numerous nutritional and industrial applications. This has given way to numerous research into the plant as a means of generating resources for the production of essential materials such as epoxidised oil for polyol formation [14, 15], biodiesel [16], etc. Plant seed attracted a lot of research interest due to its tendency of yielding oil at a viable quantity, renewable and abundant in nature. Seed is often referred to as a waste, because they are produced in a larger quantity that are more than what they might need to replant. 
As a result of this abundant nature, it is indiscriminately disposed which usually constitute a pollution to the environment. Oil from variety of seeds had been worked on, in order to find their applications, either as an industrial feedstock such as polyol in the production of polyurethane [17], emulsion paint binder [15] or transformed into a finished product such as biodiesel [16].

Penuel, et al., 2014 revealed that, Citrullus vulgaris (guna) plant stem from a family of the Cucumbitaceae or Cucurbit [18]. This family is a major family with various economically important species particularly those with edible fruits e.g. watermelon. This class of Citrullus has been found to be medicinal and nutritional advantages [18].

Ojieh, et al., 2008; Paris, 2015 reiterated that, Citrulus vulgaris is a variety of water melon, unlike other common watermelon whose flesh is sweet and red in colour, this variety of melon has a pale yellow or light green juicy flesh and tastes bitter [19, 20]. The 'guna' seed according to [21], resembles the popular 'egusi' seed, but this seed is smaller than the 'egusi' melon seed. The seed is called 'guna' in Hausa, 'egusiito' in Yoruba, 'ugbogoro' in Igbo. It is a meal for soup in northern part of Nigeria [18]. The seed is usually disposed as a waste, as only a few processed it as part of menu.

Though, biosynthesis of nanoparticles has been carried out using different plants, none has made used of synthesized lecithin to formulate stable aqueous dispersion of silver nanoparticles. A Few research study available on Citrullus vulgaris were mostly on proximate and nutritional values [18], therefore, this paper examined the feasibility of synthesizing stable aqueous dispersion of Silver nanoparticles using Citrulus vulgaris seed oil as a feedstock.

\section{Experimental Section}

Citrullus Vulgaris seed, Potassium Hydroxide, n-hexane, Hydrogen Peroxide, Distilled water, phenolphthalein, ethanol, diethyl ether, hydrochloric acid, potassium / Iodide ( $\mathrm{KI})$, sodium thiosulphate $\left(\mathrm{Na}_{2} \mathrm{~S}_{2} \mathrm{O}_{3}\right)$, Glacial acetic acid, starch indicator, silver nitrate $\left(\mathrm{AgNO}_{3}\right)$. All the reagents are of analytical grade.
2.1 Preparation of the Citrulus vulgaris Seed powder

The guna seeds (Citrulus vulgaris seed) was prepared according to the method described by Gidigbi et al., [15]. The guna seeds (Citrulus vulgaris seed) were obtained from Demsa market, in Adamawa State. It was later pilled, washed, sundried for 24 hours, before being grinded mechanically. Mesh of $0.1 \mathrm{um}$ is used to obtained a uniform size.

\subsection{Extraction of Citrulus vulgaris Seed Oil \\ The extraction of oil from Citrulus vulgaris seed} was carried out using the soxhlet extraction method as described by [16]. A total $5 \mathrm{~kg}$ of the seed was grounded and the solvent was added to the soxhlet flask in 2:1 volume ratio and was made to extract between 1 to 6 hours, at the end of which the solvent/oil mixture was evaporated and the oil recovered from the solvent. $100 \mathrm{~g}$ of powdered sample was being extracted at a time.

\section{A. Physico-chemical Parameters of Citrulus vulgaris Seed Oil \\ i. Determination of Oil Percentage Yield}

A quantity $100 \mathrm{~g}$ of the sample of the coarse -milled Citrulus vulgaris seed powder were each weighed into soxhlet and oil was extracted for six hours, at the end of which, the oil was concentrated and weighed. The percentage yield was calculated by using the formula [22]:

$$
\text { oil percentage yield }=\frac{100 \mathrm{~g} \times \text { yield } \mathrm{in} \mathrm{ml}}{100-\text { yield }}
$$

\section{ii. Acid Value}

The acid value (AV) of a fat (or oil) is the number of milligram of potassium hydroxide required to neutralize $1 \mathrm{~g}$ of the fat (or oil) without induced hydrolysis. The acid value of Citrulus vulgaris was evaluated according to method described by AOAC [23].

\section{ii. Saponification value}

The saponification value is the number of milligrams of $\mathrm{KOH}$ required to neutralize the fatty acid resulting from complete hydrolysis of Ig of fat. The Saponification value of Citrulus vulgaris was determined by the method described by $[24,25]$. 


\section{iii. Iodine value}

The iodine value determines the amount of unsaturation contained in fatty acids. It also determines the oxidation value of the fatty acids. The iodine value of the $C$. vulgaris was evaluated using the method descried by Gidigbi, et al., 2019 and Sodeke, $2005[13,26]$.

\section{iv. Peroxide value}

The peroxide value is therefore a test of the degree of deterioration of the fat or oil. It is determined by subjecting $\mathrm{KI}$ at room temperature to the oxidant effect of peroxides. The method of evaluation of peroxide value of Citrulus vulgaris was carried out according to the description of [23].

\section{B. Extraction of Lecithin}

The method described by U.S Pat 8,232,418 [27] was adopted. $70 \mathrm{mls}$ of crude Citrulus vulgaris oil was measured into a beaker and heated to $60^{\circ} \mathrm{C}$. At this temperature, few drops of hydrogen peroxide were added and mixing was applied for 1 hour, and then the precipitate was separated by centrifugation and dried at $60^{\circ} \mathrm{C}$ for 24 hours.

\section{i. Determination of Lecithin Parentage Yield}

The total lecithin extract from Citrulus vulgaris was weighed and recorded in percentage as follows [24]:

$$
\text { lecithin Percentage yield }=\frac{\text { weight of lecithin }}{\text { weight of oil }} \times 100
$$

\section{Physicochemical Properties of Lecithin}

The lecithin extract was characterized for colour, solubility in water and organic solvents.

\section{Preparation of silver nanoparticles}

The dispersion was prepared according to the method of [4]. $0.5 \mathrm{M}$ silver nitrate $\left(\mathrm{AgNO}_{3}\right)$ was prepared by weighing $0.212 \mathrm{~g}$ silver nitrate in $250 \mathrm{mls}$ volumetric flask and adding distilled water to the mark. The method described by Benjamin Robert Ayres (2013) [28] was adopted in the production of silver nanoparticle with some modifications in the concentration of the acid from 0.5 to 0.25 . M ascorbic acid was added to the mixture of $1.58 \%$ lecithin and $0.5 \mathrm{M} \mathrm{AgNO}_{3}$ in the ratio $1: 2: 3$.
E. Characterization of silver nanoparticles

i. UV-visible spectroscopy

Jenway UV/VI 6850 was used. The UV-Visible characterization was done following the method by Lei, et al., (2008) [29]. It was performed to observe the optical properties of the plant based AgNPs. After addition of $\mathrm{AgNO}_{3}$ to lecithin extract, the absorbance was taken at 24 hours and 48 hours. The final reading was taken at 48 hours from the initiation of the reaction.

\section{iit. Fourier Transform Infrared Spectroscopy}

Buck Scientific M530 FTIR was used. Fourier Transform Infrared Spectroscopy (FTIR) analysis was performed according to Gidigbi et al, (2019b) [15] to determine its chemical composition. The mixture was centrifuged at 15,000 rpm for 15 minutes to separate AgNPs from other compounds which may cause hindrance in the analysis of protein-AgNPs interaction.

\section{iiii. Atomic Force Microscopy (AFM)}

AFM is one of the foremost tools for imaging, measuring and manipulating matter of nano-scale [30]. The information is generated by scanning the surface with a mechanical probe (Cantilever). As the tip is deflected by the sample, cantilever is also deflected. The magnitude of deflection is registered by the change in the direction of LASER beam that is reflected off the end of the cantilever and detected by photodiode array.

\section{Results and Discussion}

\subsection{Percentage yield of oil}

The percentage oil yield showed that that $48.57 \%$ of the milled guna seed is oil. This oil content is quite lower than that of Watermelon seed oil which was found to be $50.0 \%$ [31], and higher than Avocado seed oil, which was reported to be $18.1 \%$ [13]. The high oil yield signifies its feasibility in industrial application.

\subsection{Physical properties of Citrulus vulgaris seed oil}

The viscosity of Citrulus vulgaris seed oil was found to be $36.93 \mathrm{~mm}^{2} / \mathrm{sec}$, this is higher than 11.80 $\mathrm{mm}^{2} / \mathrm{sec}$ reported for water melon seed oil [32]. The specific gravity and refractive index for Citrulus vulgaris oil: 0.952 and 1.446 respectively; compared to watermelon seed oil of 1.4712 refractive index value 
[31], and 1.457 reported for avocado seed oil by Gidigbi et al., (2019) [13]. The refractive index of Citrulus vulgaris still in the range of most seed oil.

The Acid Value for Citrullus vulgaris seed oil was recorded as $1.092(\mathrm{mgKOH} / \mathrm{g})$, against avocado seed oil reported as $43.86(\mathrm{~g} / 100 \mathrm{~g})$ Gidigbi et al., (2019) [13], and $2.4 \mathrm{mg} \mathrm{KOH} / \mathrm{g}$ acid value reported by [31]. Iodine value was recorded as 121.7 , compared to watermelon of iodine value of $156 \mathrm{~g} \mathrm{I} / 100 \mathrm{~g}$ (Table 1 ).

The saponification value was evaluated to be $182.00(\mathrm{mgKOH} / \mathrm{g})$, which is little higher to saponification value of water melon seed oil which is $200 \mathrm{mgKOH} / \mathrm{g}$, and avocado seed oil of $228 \mathrm{mgKOH} / \mathrm{g}$ saponification value Gidigbi et al., 2019 [13].

The peroxide value of Citrulus vulgaris was estimated to be 12.00, while that of watermelon seed oil was estimated to be 3.24 mequiv $/ \mathrm{kg}$ [31]. The ester value was estimated to be $190.0 \mathrm{mgKOH} / \mathrm{g}$ ).

Percentage yield of lecithin was found to be $1.48 \%$. The phosphate test showed light yellow colour indicating the presence of phosphate in the lecithin.

\subsection{Lecithin yield}

The solubility of lecithin in selected organic solvents and water were observed and the results recorded in Table 2.

\subsection{Production of Silver nanoparticles}

Addition of $\mathrm{AgNO}_{3}$ to the synthesized lecithin was done intermittently till a noticeable colour formation was observed. It was observed that the colour change from initial faint yellow to brown, and finally to reddish brown as the incubation time was approaching 24 hours at room temperature. This colour change is similar to colour changes observed in other literature $[4,33,34]$. The colour change confirmed the reduction of silver ions to AgNPs. The negligence in further colour change confirmed the end of the reaction.

Digital photograph from Atomic Force Microscopy showed that the nanoparticles formed were of rod shaped having the size of $50-60 \mathrm{~nm}$ and thickness of 5-6 nm only, hence they are said to be nano particles.

Table 1. Physico-chemical parameters of Citrulus vulgaris seed oil

\begin{tabular}{ll}
\hline Colour & Yellow \\
Odour & Odourless \\
Viscosity & 369.3 \\
Specific Gravity & 0.952 \\
Refractive Index & 1.446 \\
Acid value $(\mathrm{mgKOH} / \mathrm{g})$ & 1.092 \\
Iodine Value $(\mathrm{Wiji} \mathrm{s})$ & 121.7 \\
Saponification $(\mathrm{mgKOH} / \mathrm{g})$ & 182.00 \\
Peroxide value & 12.00 \\
Ester value $(\mathrm{mgKOH} / \mathrm{g})$ & 190.0 \\
\hline
\end{tabular}

Table 2. Solubility of lecithin in some liquids compare to standard

\begin{tabular}{llllll}
\hline Sample & Acetone & Chloroform & $\begin{array}{l}\text { Petroleum } \\
\text { ether }\end{array}$ & Methanol & water \\
\hline $\begin{array}{l}\text { Citrulus } \\
\text { vulgaris } \\
\text { lecithin }\end{array}$ & +++ & +++ & +++ & ++ & ++ \\
$\begin{array}{l}\text { Standard } \\
\text { Lecithin }\end{array}$ & +++ & +++ & +++ & +++ & +++ \\
\hline
\end{tabular}


3.5 Assessment and Characterisation of dispersed nanoparticles

Fourier Transformation Infrared Spectroscopy has widely been used to study the organic bonds in chemical substance and also to monitor chemical interactions of a reactants [15]. The FTIR analysis of Lecithin (Figure 1) revealed a broad absorption of $\mathrm{O}-\mathrm{H}$ stretching at $3415.05 \mathrm{~cm}^{-1}$ which revealed evidence of presence of Alcohol group. While absorption at 1645.02 $\mathrm{cm}^{-1}$ confirmed the presence of unsaturated $-\mathrm{C}=\mathrm{C}-$ in lecithin.

Figure 2 revealed the FTIR analysis of the reaction process at 10 minutes after initiation of the reaction. Multiple absorptions were observed at $35.74 .42 \mathrm{~cm}^{-1}, 34.83 .27 \mathrm{~cm}^{-1}$ and $3322.32 \mathrm{~cm}^{-1}$. $35.74 .42 \mathrm{~cm}^{-1}$ correspond to presence of $\mathrm{O}-\mathrm{H}$ bonding, while absorption at $34.83 .27 \mathrm{~cm}^{-1}$ confirmed the presence of hydrogen bonding and $3322.32 \mathrm{~cm}^{-1}$ confirmed $\mathrm{N}-\mathrm{H}$ stretching. Thus, it shows that at the addition of $\mathrm{AgNO}_{3}$, chemical interaction taking place, leading to formation of hydrogen bond between Nitrogen of $\mathrm{AgNO}_{3}$ and Hydroxyl bond of Lecithin. Furthermore, doublet absorption at 1213.53 and 1216.52 confirmed C-N stretching interaction of the reactants.
At Figure 3, the incubation time has reached 24 hours in which the FTIR revealed that the triplet absorption once observed at the 10 minutes of the reaction (figure 2) has reduced to broad $\mathrm{O}-\mathrm{H}$ stretching at $3432.76 \mathrm{~cm}^{-1}$, while absorption at $1054.42 \mathrm{~cm}^{-1}$ confirmed the presence of carboxylic compound. According to Ranganathan, and Ramachandran, 2012, presence of carboxylic plays a crucial role in the reduction of $\mathrm{AgNO}_{3}$ to $\mathrm{Ag}+$ [1]. Absorption at 1450.51 $\mathrm{cm}^{-1}$ was reported to be an indicative of the role of aromatic groups in the reduction of $\mathrm{Ag}+$ ions in the filtrate [35].

Figure 4 depicts the UV-Visible Analysis of the dispersed nanoparticles formed. After 24 hours of incubation, highest absorbance was observed in UVvisible and it remained constant after 48 hours of reaction. The highest absorbance was noted at $381.0 \mathrm{~nm}$ [36-38] suggested that the shoulder at 370 $\mathrm{nm}$ corresponded to the transverse plasmon vibration in silver nanoparticle.

Figure 5 denotes the Digital photograph from Atomic Force Microscopy. It was observed that the nanoparticles formed were of rod shaped having the size of 50-60 nm and thickness of 5-6 nm only, hence they are said to be nano particles.

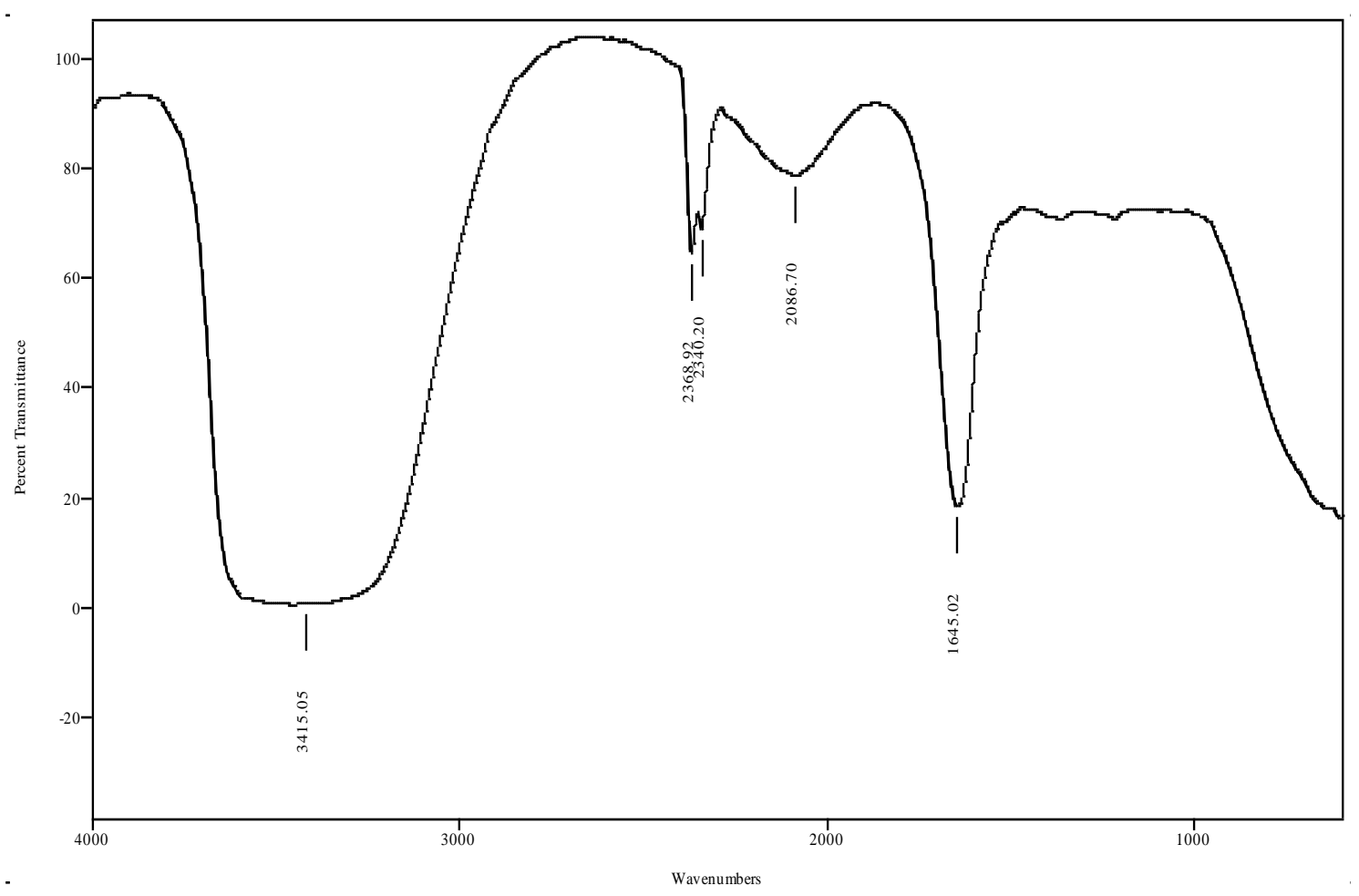

Figure 1 FTIR for lecithin 


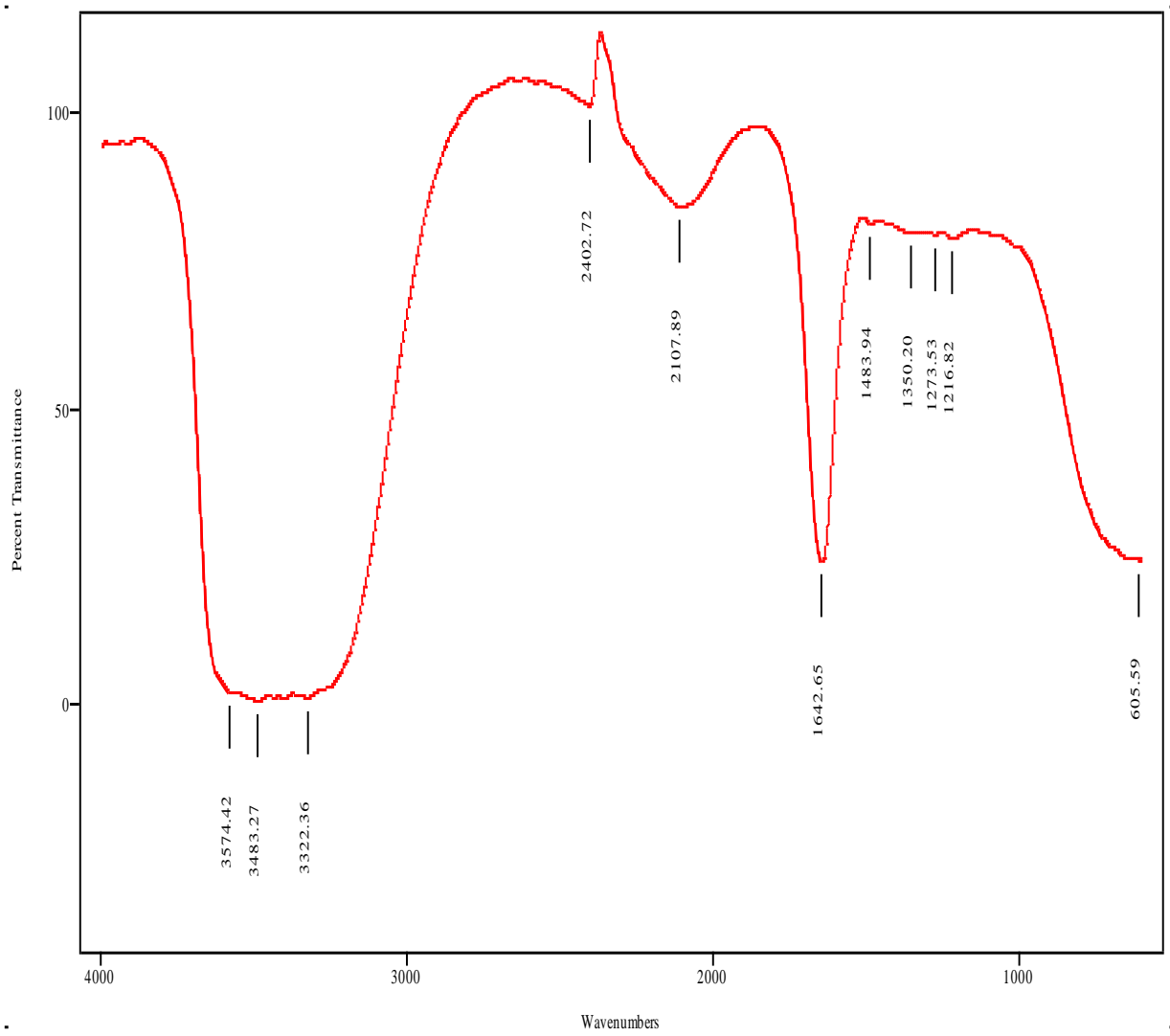

Figure 2 FTIR for lecithin and $\mathrm{AgNO}_{3}$ after 10 minutes

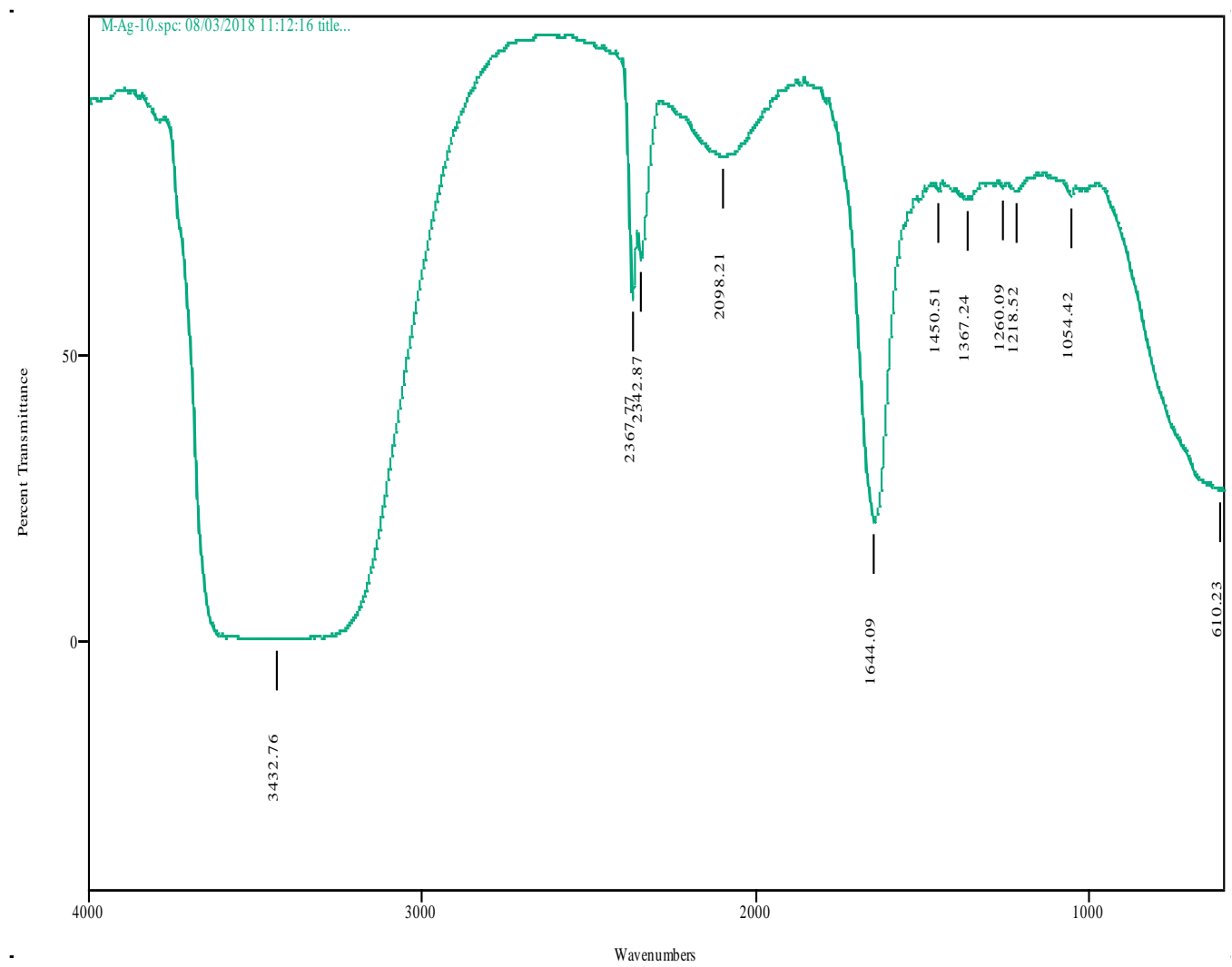

Figure 3 FTIR for lecithin and $\mathrm{AgNO}_{3}$ after 24 hours 


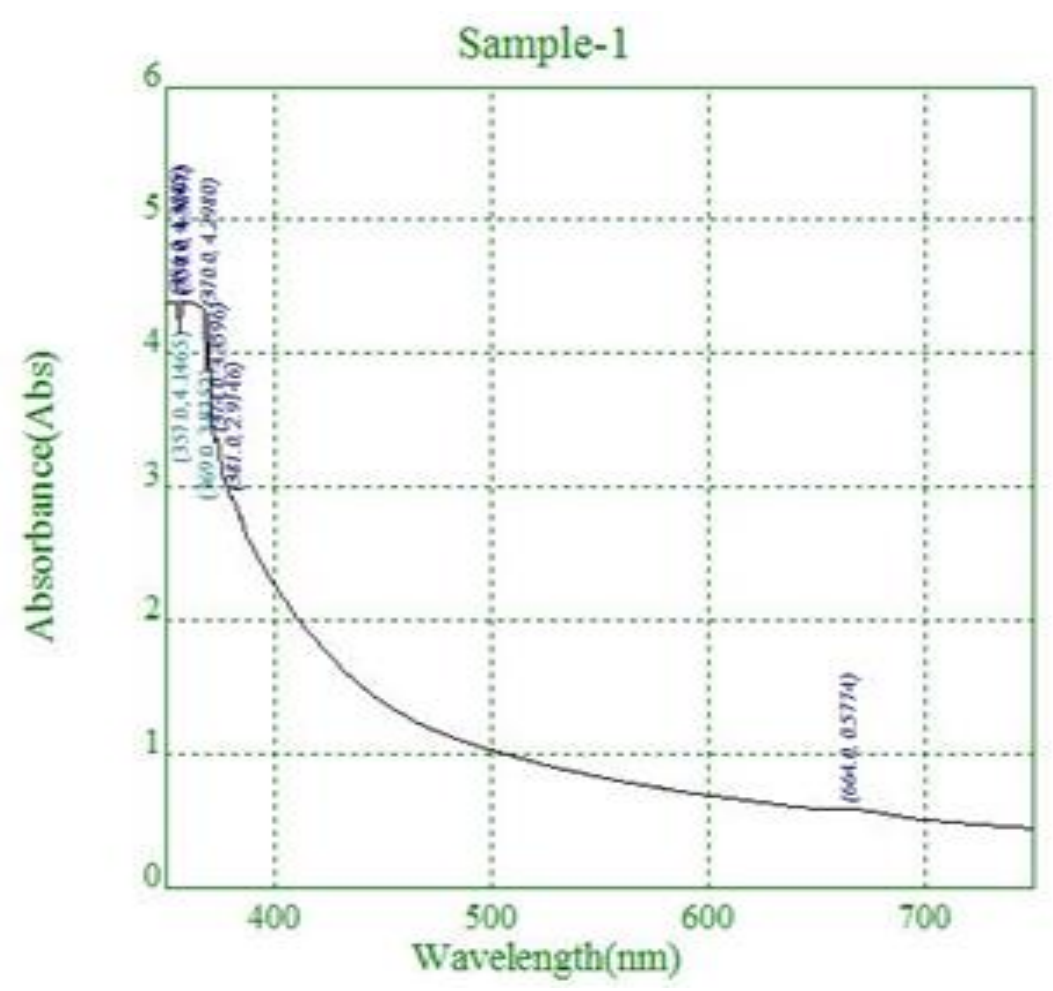

Figure 4 UV-Visible for lecithin and $\mathrm{AgNO}_{3}$ after 24 hours

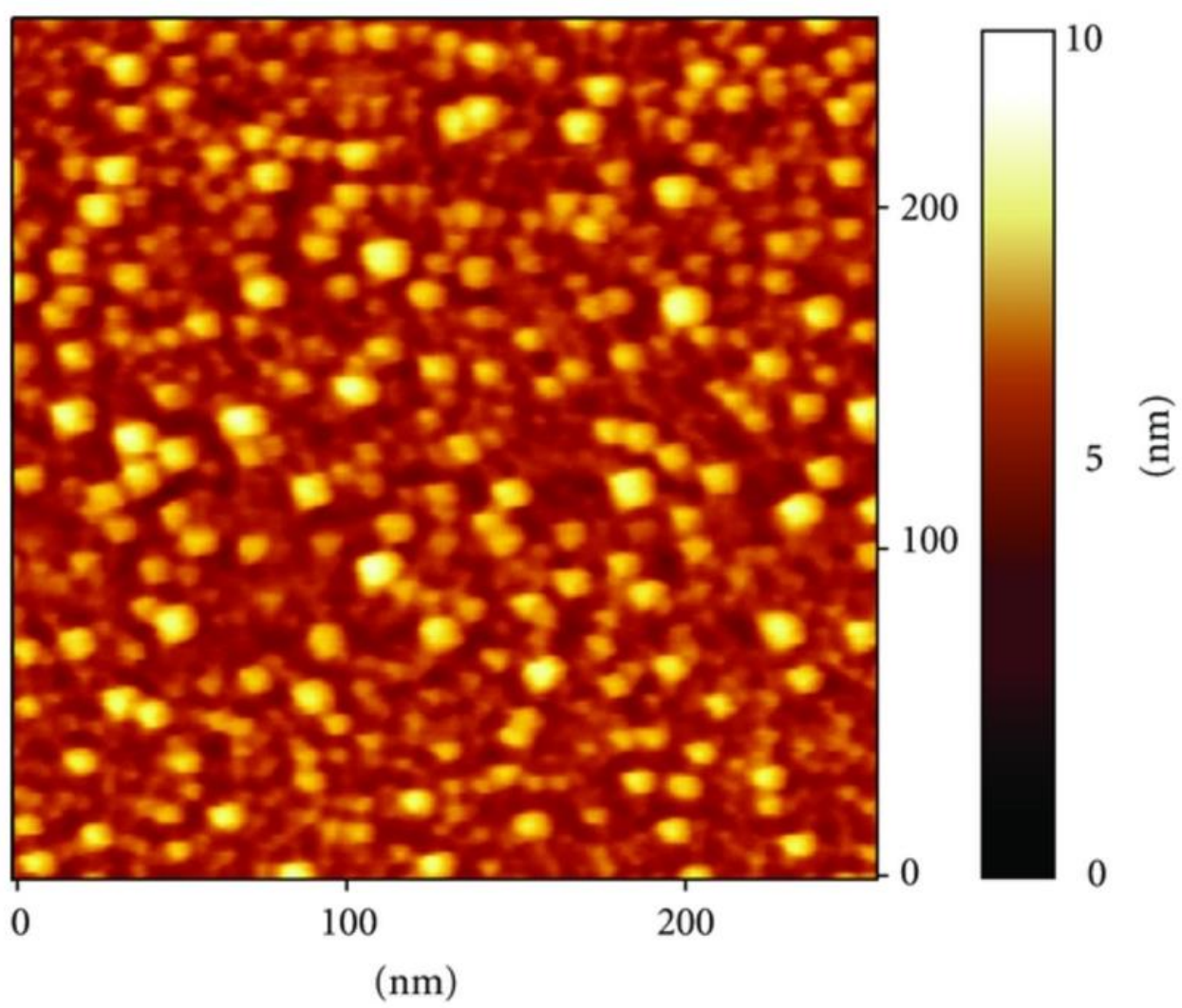

Figure 5 AFM images of the silver nanoparticles prepared by AgNO3 and lecithin 
According to Sadowski, et al., 2008, synthesized nanoparticles can be in the size range of $100 \mathrm{~nm}$, or lesser, as reported the size range of 50 to $100 \mathrm{~nm}$ in the synthesized nanoparticle [39, 40]. Sudha, et al., 2013 reported 40-80nm synthesized nanoparticle sizes [34]. Sadowski, et al., 2008 \& Nithya, and Ragunathan, 2012 noted that, the shape of the nanoparticle can be influence by drying [10, 39].

\section{Conclusion}

Silver nanoparticles was successfully synthesized from lecithin. It was observed that that Citrulus vulgaris lecithin is ideal for the production of aqueous silver nanoparticles dispersion when combined with $0.5 \mathrm{M} \mathrm{AgNO3}$ and ascorbic acid. Lecithin made from Citrulus vulgaris was slightly soluble in water and methanol. Also, Citrullus vulgaris seed oil can be used as alternative source of lecithin, in order to relieve the huge demand on maize and soya lecithin which both serve as food preservative, and as an antioxidant protector. Due to high saponification value, Citrulus vulgaris seed oil can be used in production of soap. Also, Citrullus vulgaris seed oil is a drying oil due to the high value of iodine value, and this find application in coating industries. The silver nanoparticles produced can find application in the field of nanomedicine, as it was reported that, nanoparticles of 50-60 nm size are used in vivo pharmacokinetics and cellular interaction.

\section{References}

[1] N. Ranganathan, R. Ramachandran, Synthesis of silver nanoparticles using a probiotic microbe and its antibacterial effect against multidrug resistant bacteria, African Journal of Biotechnology, 11(49) (2012) 11013-11021.

[2] L. Marinescu, D. Ficai, O. Oprea, \& A.E. Marin, Optimized Synthesis Approaches of Metal Nanoparticles with Antimicrobial Applications, Journal of Nanomaterials, (2020) 1-14. [DOI]

[3] N. Hoshyar, S. Gray, G. Bao, The Effect of Nanoparticle Size on In Vivo Pharmacokinetics and Cellular Interactions, Nanomedicine, 11(6) (2016) 673-692. [DOI]

[4] S.P. Kamala Nalini, K. Vijayaraghavan, Green Synthesis of Silver and Gold Nanoparticles using Aloe Vera Gel and Determining its Antimicrobial Properties on Nanoparticle Impregnated Cotton Fabric, Journal of Nanotechnology Research, 2 (2020) 42-50.
[5] S. Gurunathan, K. Kalishwaralal, R. Vaidyanathan, D. Venkataraman, S.R. Pandian, J. Muniyandi, N. Hariharan, S.H. Eom, Biosynthesis, purification and characterization of silver nanoparticles using Escherichia coli, Colloids and Surfaces B: Biointerfaces, 74(1) (2009) 32. [DOI] [PubMed]

[6] W.R. Li, X.B. Xie, Q.S. Shi, H.Y. Zeng, Y.S. OuYang, Y.B. Chen, Antibacterial activity and mechanism of silver nanoparticles on Escherichia coli, Applied Microbiology and Biotechnology, 85(4) (2010) 1115-22. [DOI] [PubMed]

[7] K.E. Sapsford, K.M. Tyner, B.J. Dair, J.R. Deschamps, I. Medintz, Analyzing nanomaterial bioconjugates: a review of current and emerging purification and characterization techniques, Analytical Chemistry, 83(12) (2011) 4453-88. [DOI] [PubMed]

[8] X-F. Zhang, Z-G. Liu, W. Shen, S. Gurunathan, Silver Nanoparticles: Synthesis, Characterization, Properties, Applications, and Therapeutic Approaches, International Journal of Molecular Science, 17(9) (2016) 1534. [DOI] [PubMed]

[9] S. Chernousova, M. Epple, Silver as antibacterial agent: ion, nanoparticle, and metal, Angewandte Chemie 52(6) (2013) 163653. [DOI] [PubMed]

[10] R. Nithya, R. Ragunathan, Synthesis of silver nanoparticles using a probiotic microbe and its antibacterial effect against multidrug resistant bacteria, African Journal of Biotechnology, 11(49) (2012) 11013-11021. [DOI] [PubMed]

[11] Tae-Hyun Kim, Meeju Kim, Hyung-Seok Park, Ueon Sang Shin, Myoung-Seon Gong, HaeWon Kim, Size dependent cellular toxicity of silver nanoparticles. J Biomed Mater Res A, 100 (2012) 1033-1043. [DOI] [PubMed]

[12] J. Wang, W. Lin, \& E. Cao, Surface Plasmon Resonance Sensors on Raman and Fluorescence Spectroscopy, Sensors, 17(12) (2017) 2719. [DOI]

[13] J.A. Gidigbi, A.M. Ngoshe, Martins, Aisuedion, Industrial Viability Study of the Avocado Seed Oil, International Journal of Recent Innovations in Academic Research, 3(6) (2019) 48-57.

[14] A.B. Abubakar, and J. A. Gidigbi, Development of Emulsion Paint using Hydroxylated Avocado 
Seed Oil Modified Polyvinyl Acetate Copolymer as a Binder, Journal of Chemical Society of Nigeria, 45(1) (2020) 121-125.

[15] J.A. Gidigbi, S.A. Osemeahon, A.M. Ngoshe, and A. Babanyaya, Modification of Polyvinyl acetate with Hydroxylated Avocado Seed Oil as a Copolymer Binder for possible Application in Coating Industry, International Journal of Recent Innovations in Academic Research, (2019b) 231-244.

[16] A. Sadiq, Assessment of Nigeria Sweet Orange Seed Oil for Biodiesel Production, Nigerian


(2016) 1-9.

[17] A. Ivdre, A. Abolins, I. Sevastyanova, M. Kirpluks, U. Cabulis, Rigid Polyurethane Foams with Various Isocyanate Indices Based on Polyols from Rapeseed Oil and Waste PET. Polymer, 738(12) (2020) 1-12. [DOI] [PubMed]

[18] B.L. Penuel, M.E. Khan, N.O. Maitera, Properties of proximate composition and elemental analysis of citrullus vulgaris (guna) seed, Bulletin of Environment, Pharmacology and life Science, 2(2) (2013) 39-46.

[19] G.C. Ojieh, O.M. Oluba, Y.R. Ogunlowo, K.E. Adebisi, G.O. Eidangbe, R.T. Orole, Compositional studies of Citrullus lanatus (Egusii Melon) Seed. The int. J. Nutr. Wellness., 6(1) (2008) 43.

[20] H.S. Paris, Origin and emergence of the sweet dessert watermelon, Citrullus lanatus, Annals of Botany, 116(2) (2015) 33-148. [DOI]

[21] B.L. Penuel, M.E. Khan, N.U. Ibok, J.T. Barminas, W.S. Kefas, Mineral, Anti-nutritional and amino acid composition of Citrullus vulgaris (guna) seed protein concentrate, International Journal of Biotechnology and Food Science, (2014) 121-125.

[22] M.Z. Kyari, Extraction and Characterization of Seed oils, International Agrophysics, 22 (2008) 139-142.

[23] AOAC. (2000). Official Methods of Analysis (17th Edition ed.). Washington. D.C.: Analytical Chemist.

[24] I. A. Ibrahim, A. J. Yusuf, Extraction and physicochemical analysis of Citrus sinesis seed oil (sweet orange), European Journal of Experimental Biology, 5(7) (2015) 77-81.
[25] D. Pearson, (1991). "Fats and Oils" Composition and Analysis of Food (9th Edition ed.). London: Church Hill living Stone.

[26] V.A. Sodeke, Extraction of Oil from Water Melon Seed and Analysis, Analysis Quarterly Research Service, (2005) 25-30.

[27] J. Bilbie, and R. Blaszczyk, (2013). Method for the Preparation of Lecithin. Retrieved from https/patents.google.com/patent/US8232418B $1 /$ en

[28] B.A. Ayres, (2013). Use of Soybean Lecithin in Shape Controlled Synthesis of Gold Nanopaticles. Ph.D Thesis, Portland State University, Department of Chemistry, Portland.

[29] Z. Lei, S. Mingyu, W. Xiao, L. Chao, Q. Chunxiang, C. Liang, H. Hao, L. Xiaoqing, H. Fashui, Antioxidant stress is promoted by nano-anatase in spinach chloroplasts under UV B radiation 2008, Biological Trace Element Research, 121 (2008) 69-79. [DOI] [PubMed]

[30] M. Aditi, D.K. Mishra, and N.K. Bohra, (2015). Synthesis and Characterization of Silver Nanoparticles by Azadirachta indica Leaves, Korean Journal of Chemical Engineering, 33(10) (2016) 2990-2997. [DOI]

[31] Z. Moaddabdoost, A.A. Safe Kordi, Characteristics and Composition of watermelon Seed Oil and Solvent Extraction Parameters Effects, Journal of the American Oil Chemists' Society, 87(6) (2010) 667-671. [DOI]

[32] A. Taiwo, M.O. Agbotoba, J.A. Oyedepo, M.O. Olawunmi, Effects of drying methods on properties of water melon (Citrullus lanatus ) seed oil, African Journal of Food Agriculture Nutrition and Development, 4(4) (2010) 1-10.

[33] Y. Park, Y.N. Hong, A. Weyers, Y.S. Kim, R.J. Linhardt, Polysaccharides and phytochemicals: a natural reservoir for the green synthesis of gold and silver nanoparticles, IET Nanobiotechnol, 5(3) (2011) 69-78. [DOI] [PubMed]

[34] S.S. Sudha, K. Rajamanickam, J. Rengaramanujam, Microalgae Mediated Synthesis of Silver Nanopaticles and their Antibacterial Activities against Pathgenic Bacterial, Indian Journal Experimental Biology, 52(2) (2013) 393-399. [PubMed]

[35] S. Rashmi, V. Preeti, Biomimetic synthesis and 
characterization of proteincapped silver nanoparticles, Bioresource Technology, 100 (2009) 501-504. [DOI]

[36] M.R. Gonzalez-Quijada, M.G. Alanis-Guzman, S.O. Serna-Saldiver, Ebony (Phitecellobium Fleicaule Benth) and Protein Fractionation, Solubilization Characterization and production of an Isolate, Archivos Latinoamericanos de Nutrición, 53(1) (2003) 84-9.

[37] S.S. Shankar, A. Rai, A. Ahmad, M. Sastry, Rapid synthesis of $\mathrm{Au}, \mathrm{Ag}$ and bimetallic $\mathrm{Au}$ core $\mathrm{Ag}$ shell nanoparticles using Neem (Azardirachta indica) leaf broth, Journal of Colloid and Interface Science, 275(2) (2004) 496-502. [DOI] [PubMed]

[38] H.I. Salaheldin, M.H. Almalk, G.E. Osman, Green Synthesis of Silver Nanopaticles using bovine skin gelatin and its antibacterial effect on Clinical bacterial isolates, IET Nanobiotechnology, 11(4) (2017) 420-425. [DOI] [PubMed]

[39] Z. Sadowski, H. Maliszewska, B. Grochowalska, T. Polowczyk, T. Kozlecki, Synthesis of silver nanoparticles using microorganisms, Material Science Poland, 26(2) (2008) 419-424.

[40] S. Mona, S. Ahmad, R.H. Hamid, H. Mohammad, G. Ahmad, Green synthesis of small silver nanoparticles using geranoil and its cytotoxicity against Fibrosarcoma-Wehi, Avicenna Journal of Medical Biotechnology, 1641(2) (2009) 111-115. [PubMed]

\section{Authors" contribution}

All the authors equally contributed to this work.

\section{Competing Interests}

The authors declare that there are no personal, organizational or financial conflicts of interest.

\section{Funding}

No funding was received for conducting this study.

\section{Does this article screened for similarity? Yes}

\section{Conflict of interest}

The authors have no conflicts of interest to declare that they are relevant to the content of this article.

\section{About the License}

(c) The author(s) 2021. The text of this article is open access and licensed under a Creative Commons Attribution 4.0 International License. 